\title{
HPV DNA and Pap smear test results in cases with and without cervical pathology
}

\author{
Servikal patolojisi olan ve olmayan olgularda HPV DNA ve Pap smear test sonuçlart \\ Sabit Sinan Özalp ${ }^{1}$, Tercan Us ${ }^{2}$, Emine Arslan ${ }^{1}$, Tufan Öge ${ }^{1}$, Nilgün Kaşifoğlu ${ }^{2}$ \\ 'Department of Obstetrics and Gynecology, Faculty of Medicine, Eskişehir Osmangazi University, Eskişehir, Turkey \\ ${ }^{2}$ Department of Microbiology, Faculty of Medicine, Eskişehir Osmangazi University, Eskişehir, Turkey
}

\section{Abstract}

Objective: The aim of the study was to determine the HPV prevalance and its relation to Pap smear, colposcopy and colposcopy directed biopsy in our region of Eskisehir, Turkey.

Material and Methods: A total of 615 women who applied to the outpatient clinic between December 2009 and December 2010 constituted our study population. All patients underwent pelvic examination and Pap smear sampling. Patients who had pathological cervical appearance or Pap smear results of ASCUS, AGUS, LSIL or HSIL were referred to colposcopy. Cervical samples for HPV DNA were taken from the patients before Pap smear sampling during the routine examination or before the colposcopic evaluation.

Results: Twenty six of 615 patients (4\%) were HPV positive. Of these 26 patients, 12 were positive for HPV type 16, 3 for type 18, 3 for type 51,2 for type 6,1 for type 52,1 for type 33,1 for type 16 and type 31,1 for type 6 and 52,1 for type 56 and 90,1 for type 39 and 66 . In 4 patients with cervical cancer, and in 3 of 4 CIN III cases both HPV DNA and Pap smear were positive. In the Pap smear examination of 615 patients, cytology revealed 35 ASCUS (5.6\%) 4 AGUS (0.6\%), 2 CIN I (0.3\%) results who were negative for HPV DNA. These patients with abnormal cytology $(n=41)$ underwent colposcopy directed biopsy, there were 3 CIN I and 1 CIN III and all the other cervical biopsy results of these patients were benign (inflammation, chronic cervicitis).

Conclusion: HPV positivity in our hospital setting is low which is compatible with other studies in Turkey. In positive HPV cases there is a good correlation between HPV type and positive cervical biopsy results. (J Turkish-German Gynecol Assoc 2012; 13: 8-14)

Key words: HPV DNA, Pap smear, colposcopy directed biopsy

Received: 14 August, 2011

Accepted: 11 September, 2011

\section{Özet}

Amaç: Çalışmanın amacı Türkiye'nin Eskişehir bölgesinde HPV prevalansı ve bunun Pap smear, kolposkopi ve kolposkopik biopsi ile ilişkisini belirlemektir.

Gereç ve Yöntemler: Aralık 2009 ile Aralık 2010 tarihleri arasında polikliniğimize başvuran 615 hasta çalışma grubumuzu oluşturdu. Bütün hastalara pelvik muayene yapılıp, hastaların hepsinden Pap smear alındı. Serviksinde patolojik görünüm olan hastalara veya Pap smear sonucu ASCUS, AGUS, LSIL veya HSIL olan hastalara kolposkopik inceleme yapıldı. Hastalardan ya rutin değerlendirme sırasında Pap smear alınmadan önce ya da kolposkopik muayene öncesinde HPV DNA için servikal örnek alındı.

Bulgular: Altıyüzonbeş hastanın 26'sı (\%4) HPV pozitifti. Bu 26 hastanın 12'sinde HPV tip 16, 3 tanesinde tip 18, 3 tanesinde tip 51, 2 tanesinde tip 6, 1 tanesinde tip 52, 1 tanesinde tip 33, 1 tanesinde tip 16 ve tip 31, 1 tanesinde tip 6 ve 52,1 tanesinde tip 56 ve 90, 1 tanesinde tip 39 ve 66 mevcuttu. Serviks kanseri olan 4 hasta ve CIN III olan 4 hastanın 3'ünde hem HPV DNA hem de Pap smear pozitifti. Altıyüzonbeş hastanın Pap smear sonuçlarına bakıldığında HPV DNA negatif olan 35 ASCUS (\%5.6), 4 AGUS (\%0.6), 2 CIN I (\%0.3) olan hasta vardı. Anormal sitolojisi olan bu 41 hastaya kolposkopik biopsi yapıldı ve sonuçta sadece 3 hastada CIN I, 1 hastada CIN III varken kalan hastaların biopsi sonuçları benigndi (inflamasyon, kronik servisit).

Sonuç: Hastanemizde yapılan bu çalışmada elde edilen HPV oranlanı Türkiye'de yapılan diğer çalışmalarla uygun olarak düşük bulundu. HPV pozitif olan vakalarda HPV tipi ile pozitif servikal biopsi sonuçları arasında kuvvetli bir korelasyon mevcuttur.

(J Turkish-German Gynecol Assoc 2012; 13: 8-14)

Anahtar kelimeler: HPV DNA, Pap smear, kolposkopik biopsi

Geliş Tarihi: 14 Ağustos 2011

Kabul Tarihi: 11 Eylül 2011

\section{Introduction}

Human papilloma virus (HPV) is known as the most common venereal disease. More than 200 types of HPV are known and more than 100 of them cause diseases in humans in a wide spectrum, varying from simple warts to genital cancers. Viral infection in the genital region may result in tumour development, which may cause genital region cancers such as cervical cancer.
Diagnosis of HPV starts with clinical suspicion and certain diagnosis can be attained by histological, cytological examinations and molecular methods looking for HPV DNA. At present, there are various molecular methods for detecting HPV DNA. Expectation from these methods is to detect high grade lesions and risk of developing high grade lesions and also to detect women with low risk.

In our study, we aimed to find the HPV prevalence in the Eskişehir region and to find the relationship between

Address for Correspondence: Emine Arslan, Natura Sitesi, Çamlıca Mahallesi, Güfte Sok. No: 2 D1 Blok Daire: 5 Eskişehir, Turkey Phone: +905054752730 e.mail: ekaranfildr@gmail.com

(C) Copyright 2012 by the Turkish-German Gynecological Education and Research Foundation - Available online at www.jtgga.org doi:10.5152/jtgga.2011.69 
Pap smear, colposcopically directed biopsy and HPV DNA positivity.

\section{Material and Methods}

Six hundred and fifteen women applied to ESOGU Medical Faculty Gynaecology outpatient clinic between December 2009 and December 2010 were included in this study. Patients were randomly selected as one from all ten patients.

All patients were informed about the study and all of them filled the form which was prepared for this study. Patients who were sexually active and who had uterus and cervix were included in the study. Ninety-seven of 712 patients who did not give informed consent to take part in the study were excluded. All patients underwent pelvic examination and Pap smear sampling. Patients who had pathological cervical appearance or Pap smear results of ASCUS, AGUS, LSIL or HSIL were referred to colposcopy. According to the above criteria one hundred and ninety four patients underwent colposcopic evaluation. Cervical samples for HPV DNA were taken from the patients before Pap smear sampling during the routine examination or before the colposcopic evaluation (Figure 1).

Cervical Pap smears and biopsies were examined by the pathologists unaware of the study.

Cervical samples of patients were taken and sent to the Microbiology Laboratory in Hybrid Capture Specimen Transport Medium (DIGENE). These specimens were stored at $-70^{\circ}$ until they were studied. HPV DNA was extracted from the samples by spin column method with Qiagen PureArt DNA Mini kit (Qiagen $\mathrm{GmbH}$, Hilden/Germany). Then PCR was performed with each of prime Mix A and Mix B (Mix My 11/09 and Mix 125) provided by the LCD-Array HPV 3.5 kit (CHIPRON GmbH, Germany) on Gene Amp PCR system 9700.

Amplification was run as follows: Initial denaturation of $96^{\circ} \mathrm{C}$ for 3 minutes, followed by 42 cycles of $94^{\circ} \mathrm{C} / 1 \mathrm{~min}, 45^{\circ} \mathrm{C} / 1 \mathrm{~min} 30$ sec, $72^{\circ} \mathrm{C} / 1 \mathrm{~min} 30 \mathrm{sec}$, and finally 3 minutes at $72^{\circ} \mathrm{C}$. Following this, amplification hybridization was performed; $22 \mu \mathrm{l}$ of modulator per one patient were mixed in an Eppendorf tube. Then $10 \mu \mathrm{l}$ of DNA was added. Thirty $\mu \mathrm{l}$ of this solution was added to each well of the LCD-Array. Eight patients were studied on one slide.

The slide was incubated for 30 minutes at $35^{\circ} \mathrm{C}$. Then the slide was rinsed 3 times in washing solutions and dried by centrifugation at $1000 \mathrm{rpm}$. "A 30" $\mu$ l labelling solution mix was added to each well and slides were incubated 5 minutes at room temperature. Then washing steps were repeated and the slides were dried. $30 \mu \mathrm{l}$ of stain solution were added on each well and incubated for 3 minutes at room temperature. The slides were rinsed and dried. After this step, hybridized sports were evaluated by automated analysis system (Computerized Kodak Prime Film 2700-Slide Reader Software). Paired spots on the wheel of the slides were reported as HPV types.

All data analyses were done by SPSS 15.0 and SigmaStat 3.5 package programs. Continuous quantitative data were

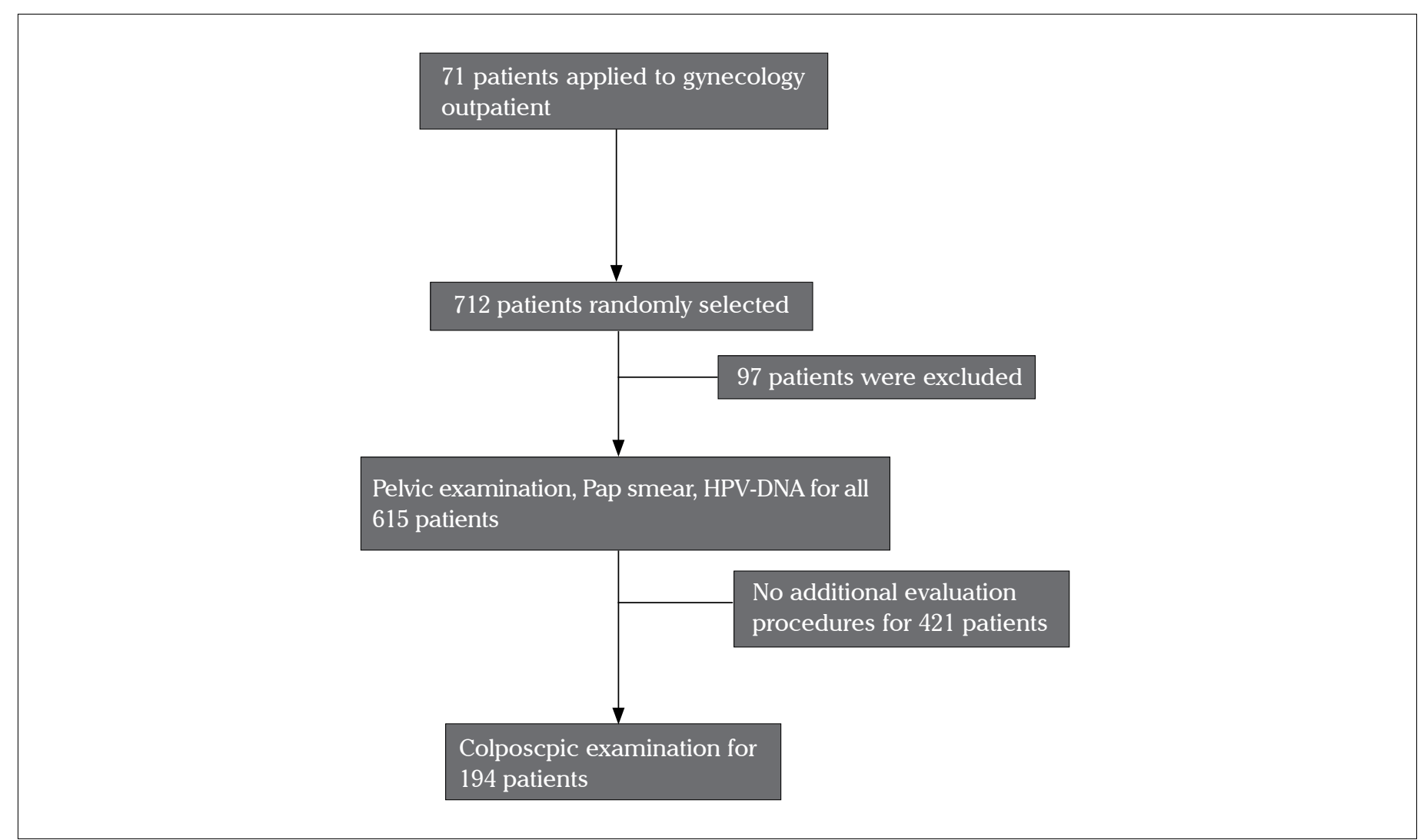

Figure 1. Patient selection and evaluation algorithm 
denoted as; n, mean and standard deviation; qualitative data were denoted as $\mathrm{n}$ and percentage. One Way Anova and T-Test were used due to group number to analyse data consist with independent measurements showing normal distribution. Pearson Correlation Test was used to determine the relationship between the groups. To analyze the variations that do not distribute normally, Kruskal Wallis and Mann-Whitney U tests were used. Spearman Correlation Test was used to determine relationship between the groups. Data in a categorical structure were analyzed by Chi square test. A p value $<0.05$ was accepted as significant.

Table 1. Demographic characteristics

\begin{tabular}{|c|c|c|c|}
\hline & HPV DNA positive & HPV DNA negative & $\mathbf{p}$ \\
\hline Age (years) & $35.7 \pm 11.8$ & $38.7 \pm 10.7$ & $>0.05$ \\
\hline Gravidy (n) & $2.3 \pm 2.2$ & $2.6 \pm 1.9$ & $>0.05$ \\
\hline Parity (n) & $1.4 \pm 1.2$ & $1.7 \pm 1.2$ & $>0.05$ \\
\hline Abortus (n) & $0.6 \pm 0.3$ & $0.7 \pm 0.3$ & $>0.05$ \\
\hline Duration of Marriage (years) & $14.4 \pm 12.6$ & $17.1 \pm 11.6$ & $>0.05$ \\
\hline Age of Partner (years) & $39.6 \pm 12.8$ & $42.1 \pm 11.2$ & $>0.05$ \\
\hline \multicolumn{3}{|l|}{ Contraceptive Method } & \multirow{9}{*}{$>0.05$} \\
\hline None (n) & 11 & 295 & \\
\hline Oral Contraceptive (n) & 3 & 39 & \\
\hline IUD (n) & 2 & 54 & \\
\hline Condom (n) & 5 & 58 & \\
\hline Coitus Interruptus (n) & 3 & 99 & \\
\hline Depo Progesterone (n) & 0 & 1 & \\
\hline Tubal Ligation (n) & 2 & 34 & \\
\hline Others (n) & 0 & 9 & \\
\hline Duration of Contraception (years) & $8.2 \pm 8.0$ & $7.3 \pm 7.1$ & $>0.05$ \\
\hline Coitus per Week (n) & $2.0 \pm 1.1$ & $1.7 \pm 1.0$ & $>0.05$ \\
\hline Gynaecological Examination per life (mean) (n) & $6.5 \pm 6.3$ & $8.1 \pm 7.5$ & $>0.05$ \\
\hline \multicolumn{4}{|l|}{ Place of Birth } \\
\hline Urban (n) & 15 & 337 & \multirow[b]{2}{*}{$>0.05$} \\
\hline Rural (n) & 11 & 252 & \\
\hline \multicolumn{4}{|l|}{ Place of residence } \\
\hline Urban (n) & 20 & 406 & \multirow{2}{*}{$>0.05$} \\
\hline Rural (n) & 6 & 183 & \\
\hline \multicolumn{3}{|l|}{ Cigarette smoking } & $>0.05$ \\
\hline Positive (n) & 9 & 139 & \multirow{2}{*}{$>0.05$} \\
\hline Negative (n) & 17 & 450 & \\
\hline
\end{tabular}

Table 2. The relationship between HPV positivity and cytology

\begin{tabular}{|l|c|c|c|c|}
\hline \multicolumn{2}{|c|}{} & Normal Pap smear & Pathological Pap smear & p \\
\hline HPV-DNA result & Negative & 545 & 44 & $<0.05$ \\
\hline & Positive & 19 & 7 & $<$ \\
\hline
\end{tabular}

\section{Results}

Demographic characteristics of the patients included in the study are shown in Table 1.

Mean age of the women included in the study was $38.6 \pm 10.8$ years. Mean age was $35.7 \pm 11.8$ years in the HPV DNA positive group; and 38.7 \pm 10.7 years in HPV DNA negative group; and there was no significant difference between the two groups. $538(87 \%)$ of the patients included in the study were married, $24(3.9 \%)$ were single and $53(8.6 \%)$ of them were widowed. 
HPV-DNA was positive in $26(4.2 \%)$ of 615 patients, 14 (7.2\%) of 194 patients who underwent colposcopy and 12 (2.8\%) of 421 patients to whom colposcopy was not applied $(\mathrm{p}<0.05)$.

There was a significant difference between the two groups in terms of marital status and number of sexual partners.

Pap smear results were significantly different between the two groups (Table 2).

HPV-DNA types and Pap smear results of the HPV-DNA positive patients are shown in Table 3.

The relationship between HPV presence, type of the HPV and histology among patients examined by colposcopy is shown in Table 4. Colposcopy directed biopsy was not applied to 3 of 12 HPV type 16 positive cases, 1 of 3 HPV type 18 cases, 2 of $3 \mathrm{HPV}$ type 51 cases, 1 of 2 type 6 cases and type 33, 56 and 90,39 and 66, 52 cases (n:1) as pelvic examinations and Pap smears of these patients were normal.
One of 12 patients with Type 16 HPV DNA had LGSIL on Pap smear and the Pap smear of the patient who was positive for type 16 and type 31 HPV DNA was reported as HGSIL (Table 3). Three patients with Type 16 HPV DNA and the patient with Type 18 HPV DNA were diagnosed as cervical cancer; their Pap smears were positive for malignancy and the Pap smear of the one patient who had Type 51 HPV DNA positive was reported as HGSIL; her colposcopic biopsy result was found to be CIN 3 (Table 3,4 ).

According to Pap smear results, all 35 patients that were detected as ASCUS were HPV DNA negative, whereas only 3 of those 35 patients' colposcopic biopsy results were CIN 1, 1 patient's biopsy result was CIN 3, the other 31 patients' biopsy results were reported as benign. The algorithm of patient evaluation is given in Figure 2. All AGUS, LSIL and HSIL patients at HPV-DNA negative group had benign pathology results. In the HPV-DNA positive group, 1 LGSIL patient's biopsy and 2 HGSIL patients' colposcopic biopsy revealed CIN 3.

Table 3. The relationship between HPV type and cytology in HPV-DNA positive patients

\begin{tabular}{|c|c|c|c|c|c|c|c|}
\hline \multirow{2}{*}{\multicolumn{2}{|c|}{ HPV Type }} & \multicolumn{6}{|c|}{ PAP SMEAR } \\
\hline & & \multirow{2}{*}{$\begin{array}{c}\text { Negative } \\
8\end{array}$} & \multirow{2}{*}{$\begin{array}{c}\text { ASCUS } \\
-\end{array}$} & \multirow{2}{*}{$\begin{array}{c}\text { AGUS } \\
-\end{array}$} & \multirow{2}{*}{$\begin{array}{c}\text { LSIL } \\
1\end{array}$} & \multirow{2}{*}{$\begin{array}{c}\text { HSIL } \\
-\end{array}$} & \multirow{2}{*}{$\begin{array}{c}\text { Cance } \\
3\end{array}$} \\
\hline 16 & $(n=12)$ & & & & & & \\
\hline 18 & $(n=3)$ & 2 & - & - & - & - & 1 \\
\hline 51 & $(n=3)$ & 2 & - & - & - & 1 & \\
\hline 6 & $(n=2)$ & 2 & - & - & - & - & - \\
\hline 52.6 & $(n=1)$ & 1 & - & - & - & - & - \\
\hline 16.31 & $(n=1)$ & - & - & - & - & 1 & - \\
\hline 56.90 & $(n=1)$ & 1 & - & - & - & - & - \\
\hline 39.66 & $(n=1)$ & 1 & - & - & - & - & - \\
\hline 33 & $(n=1)$ & 1 & - & - & - & - & - \\
\hline 52 & $(n=1)$ & 1 & - & - & - & - & - \\
\hline HPV I & A $\quad(-)$ & 545 & 35 & 4 & 3 & 2 & - \\
\hline
\end{tabular}

Table 4. The relationship between HPV presence, type and histology among the patients examined by colposcopy

\begin{tabular}{|l|c|c|c|c|c|}
\hline \multirow{2}{*}{ HPV Type } & \multicolumn{5}{|c|}{ Colposcopy directed biopsy } \\
\cline { 2 - 6 } & Negative & CIN I & CIN II & CIN III & \multicolumn{1}{c|}{ Ca } \\
\hline 16 & 5 & - & - & - & 1 \\
\hline 16 and 31 & 1 & - & - & 1 & - \\
\hline 51 & - & - & - & - & - \\
\hline 33 & - & - & - & - & - \\
\hline 52 and 6 & - & - & - & - & - \\
\hline 56 and 90 & - & - & - & - \\
\hline 52 & - & - & - & - \\
\hline 39 and 66 & 1 & - & - & - \\
\hline 6 & 177 & 8 & 0 & - \\
\hline Total & - & - & - & - \\
\hline
\end{tabular}




\section{Discussion}

Cervical cancer is a significant health problem especially in developing countries. For prevention, early detection and treatment of the preinvasive lesions that can progress to cervical cancer is very important.

In the United States (in 2009), the number of estimated new cases of invasive cervical cancer was 1270 and expected number of cancer related deaths was 4210. This represents approximately 1.5 percent of cancer deaths in women (1). Cervical cancer is the second most common cancer among women worldwide, with $83 \%$ of cases occurring in developing countries (2).

HPV infection is detected in $99.9 \%$ of the cervical cancer cases. Although the infection improves without any treatment in most women, the women with persisting HPV infection are at risk for CIN II, III and cervical cancer.

The Papanicolaou (Pap) smear screening test for cervical cancer was introduced in the United States in 1941, and led to the first systematic effort to detect early cancer. It has been associated with a sustained reduction in cervical cancer incidence and mortality.
The Pap smear has become a model for cancer screening. However, the effectiveness of Pap smear screening for cervical cancer has never been demonstrated in a randomized trial. Cervical cancer screening remains an evolving field with ongoing reevaluation of Pap smear screening practices and development of new screening technologies.

The Pap smear is designed as a screening test (to be administered to asymptomatic patients), rather than a diagnostic test (to confirm or refute the suspicion of disease). Reports of test sensitivity and specificity vary significantly. In a systematic review conducted by Nanda et al., sensitivity of Pap smear was found between $30 \%-87 \%$, specificity was found between $86 \%$ $100 \%$ (3).

Although the Pap smear is the routinely used screening tool for cervical cancer, HPV-DNA screening in cervical samples is recommended as either an altenative or adjunvtive treatment to cervical cytology.

Considerable interobserver variability in smear interpretation is seen, although variability decreases as the grade of cervical intraepithelial neoplasia grade increases (4).

In a review by Cuzick et al. (5), more than 60,000 women were included. The sensitivity and specificity of HPV testing were

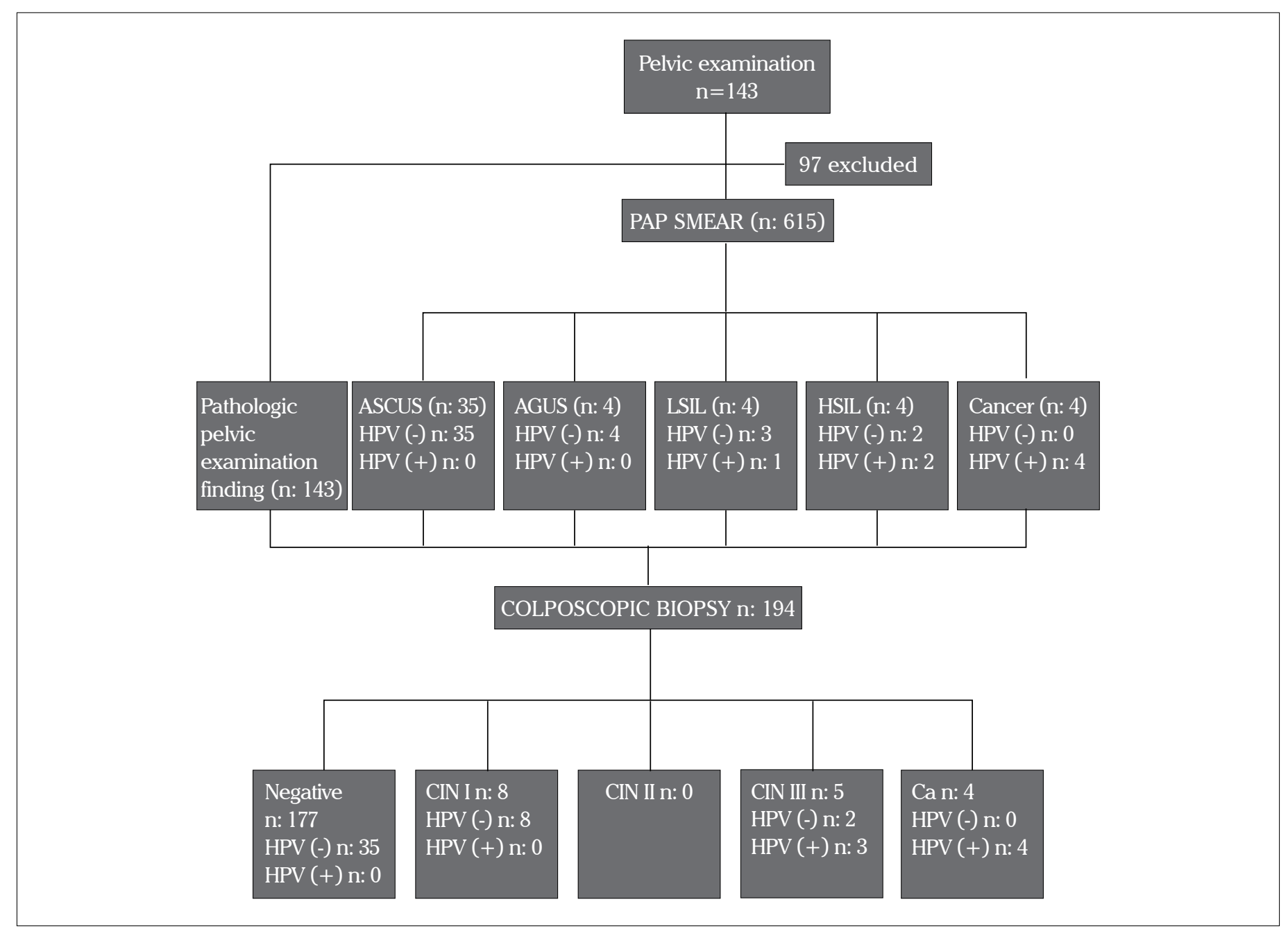

Figure 2. The algorithm of patient evaluation 
compared with routine cytology. For lesions $\geq$ CIN 2, HPV DNA was more sensitive ( $96.1 \%$ vs. $53.0 \%$ ) but less specific ( $90.7 \%$ vs. $96.3 \%)$. According to that study, HPV sensitivity was uniformly high for all age groups, whereas the sensitivity of cytology was substantially better in women over the age of 50 than in younger women $(79.3 \%$ vs. $59.6 \%)$. The specificity of both tests increased with age.

Kim et al. (6) showed that DNA testing had the potential to improve health benefits at a reasonable cost compared with current screening policies. According to Denny et al. (7), HPV DNA screening for the prevention of cervical cancer is particularly more usable for women older than 30 years, in the triage of women with equivocal cytology and for the post-treatment follow-up of women.

In the study that aimed to compare the sensitivity and specificities of HPV-DNA and Pap smear for 10154 women between the ages of 30-69, Koiopoulos et al. (8) found the sensitivity of HPV-DNA 94.6\%, sensitivity of Pap smear 55.4\%; specificity of HPV-DNA 94.2\%, specificity of Pap-smear 96.8\% for CIN II and III. When two tests are used together, sensitivity was $100 \%$ and specificity was $92.5 \%$.

In the current study, in the HPV-DNA negative group, the Pap smear results of 35 patients were ASCUS, 3 patients were LGSIL, 2 patients were HGSIL. Only 3 of those 35 patients' colposcopic biopsy results were CIN 1, 1 patient's biopsy result was CIN 3, the other 31 patients' biopsy results were reported as benign. All AGUS, LSIL and HSIL patients at HPV-DNA negative group had benign pathology results. In the HPV-DNA positive group, 1 LGSIL patient's biopsy and 2 HGSIL patients' colposcopic biopsy revealed CIN 3 patients positive HPV-DNA and tumour cells in their Pap smear were diagnosed as cervical cancer. HPV-DNA was found positive in 19 patients who had normal Pap smears. Based on this information, it can be said that the HPV DNA test is very useful in early detection of cervical lesions and for the follow up of the patients with ASCUS Pap smears. Several studies showed that HPV-DNA is as cost-effective as recurrent Pap smears. In cases with ASCUS, if HPV DNA is evaluated, $50 \%$ of colposcopies will be unnecessary (9).

In our study, 3 of the 4 cervical cancer patients were positive for HPV type 16, and 1 of the cervical cancer patient was positive for HPV type 18. HPV type 16 and 18 are the most common HPVtypes found in cervical cancer cases. HPV type 16 is the most oncogenic type and type 18 is the second common. Munoz et al. classified 15 HPV types as high risk (16, 18, 31, 33, $35,39,45,51,52,56,58,59,68,73$, and 82 ), 3 types as probably high risk $(26,53$, and 66$)$ and 12 types as low risk (6, 11, 40, 42, 43, 44, 54, 61, 70, 72, 81, and CP6108) (10).

In this study, HPV was positive in $4.2 \%$ of the study population and its incidence was $7.2 \%$ in the high risk group. In the studies about HPV from Turkey, the incidence was reported between $2.1 \%$ and $16.4 \%$ (11-16). In the study by de Sanjose et al. (17), overall HPV prevalence in 157879 women with normal cervical cytology was estimated to be $10.4 \%$ (95\% CI 10.2-10.7). Corresponding estimates by region were Africa 22.1\% (20.923.4), Central America and Mexico 20.4\% (19.3-21.4), northern America 11.3\% (10.6-12.1), Europe 8.1\% (7.8-8.4), and Asia 8.0\% (7.5-8.4). In all world regions, HPV prevalence was highest in women younger than 35 years of age, decreasing in women of older age. In Africa, the Americas, and Europe, a clear second peak of HPV prevalence was observed in women aged 45 years or older. Similar to our study, Monsonego et al. (18) found that the HPV incidence was significantly higher in the patients who underwent colposcopic biopsy because of abnormal Pap smears compared to the control group. As a result, it can be concluded that in this region, HPV-DNA incidence is lower. It may be because of traditions and customs, perspective of sexual life, and form of sexual behaviours.

Because of the definite causal relationship between HPV and perinvasive or invasive cervical pathologies, it will continue to exist as one of the most emphasized microorganisms. Several studies have shown the usefulness of HPV-DNA testing in the triage of patients with abnormal cytology or as a primary test. If HPV-DNA tests have a reasonable cost, it will be possible to use it commonly for the socially based screening programmes.

\section{Conflict of interest}

No conflict of interest was declared by the authors.

\section{References}

1. Jemal A, Siegel R, Ward E, Hao Y, Xu J, Thun MJ. Cancer statistics, 2009. CA Cancer J Clin 2009; 59: 225-49. [CrossRef]

2. Parkin DM, Bray F, Ferlay J, Pisani P. Global cancer statistics, 2002. CA Cancer J Clin 2005; 55: 74-108. [CrossRef]

3. Nanda K, McCrory DC, Myers ER, Bastian LA, Hasselblad V, Hickey JD, et al. Accuracy of the Papanicolaou test in screening for and follow-up of cervical cytologic abnormalities: a systematic review. Ann Intern Med 2000; 132: 810-9.

4. Stoler MH, Shiffman M. Interobserver reproducibility of cervical cytologic and histologic interpretations: realistic estimates from the ASCUS-LSIL Triage Study. JAMA 2001; 285: 1500-5. [CrossRef]

5. Cuzick J, Clavel C, Petry KU, Meijer CJ, Hoyer H, Ratnam S, et al. Overview of the European and North American studies on HPV testing in primary cervical cancer screening. Int J Cancer 2006; 119: 1095-101. [CrossRef]

6. Kim JJ, Wright TC, Goldie SJ. Cost-effectiveness of human papillomavirus DNA testing in the United Kingdom, The Netherlands, France, and Italy. J Natl Cancer Inst 2005; 97: 888-95. [CrossRef]

7. Denny LA, Wright TC Jr. Human papillomavirus testing and screening. Best Pract Res Clin Obstet Gynaecol 2005; 19: 501-15. [CrossRef]

8. Koliopoulos G, Arbyn M, Martin-Hirsch P, Kyrgiou M, Prendiville W, Paraskevaidis E. Diagnostic accuracy of human papillomavirus testing in primary cervical screening: A systematic review and meta-analysis of non-randomized studies. Gynecol Oncol 2007; 104: 232-46. [CrossRef]

9. Kirby TO, Huh WK. HPV triage of patients with ASCUS cervical pap smears: Review Article. Sexuality, Reproduction and Menopause 2004; 2: 146-53. [CrossRef]

10. Munoz N, Bosch FX, de Sanjose S, Herrero R, Castellsague X, Shah KV, et al. Epidemiologic classification of human papillomavirus types associated with cervical cancer. N Engl J Med 2003; 348: 518-27. [CrossRef]

11. Inal MM, Köse S, Yildirim Y, Ozdemir Y, Töz E, Ertopçu K, et al. The relationship between human papillomavirus infection and cervical intraepithelial neoplasia in Turkish women. Int J Gynecol Cancer 2007; 17: 1266-70. [CrossRef]

12. Tuncer M, Cancer control in Turkey 2008, The Ministry of Health of the Republic of Turkey, Department of Cancer Control, Ministry Publication number: 740, Ankara, Ministry of Health of Turkey) 
13. Vardar MA, Altıntaş A, Doran F, Arıdoğan N, Demir C, Burgut R, et al. Human papillomavirus detection in cervical smears and cervical tissue excised by the Loop Electrosurgical Excision Procedure (LEEP) Diagnostic value of cytology, colposcopy and histology. Eur J Gynaecol Oncol 1995; 16: 494-9.

14. Altuglu I, Terek MC, Ozacat T, Ozsaran AA, Bilgic A. The prevalence of human papilloma virus DNA in women with mucopurulent endocervicitis. Eur J Gynaecol Onncol 2002; 23: 166-8.

15. Ozcelik B, Serin IS, Gokahmetoglu S, Basbug M, Erez R. Human papillomavirus frequency of women at low risk of developing cervical cancer: a preeliminary study from a Turkish university hospital. Eur Gynaecol Oncol 2003; 24: 157-9.
16. Ozturk S, Kaleli I, Kaleli B, Bir F. Investigation of human papillomavirus DNA in cervical specimens by hybrid capture assay. Microbiyol Bul 2004; 38: 223-32.

17. de Sanjosé S, Diaz M, Castellsagué X, Clifford G, Bruni L, Muñoz N, et al. Worldwide prevalence and genotype distribution of cervical human papillomavirus DNA in women with normal cytology: a meta-analysis. Lancet Infect Dis 2007; 7: 453-9. [CrossRef]

18. Monsonego J, Bohbot JM, Pollini G, Krawec C, Vincent C, Merignargues I, et al. Performance of the Human papillomavirus (HPV) test in prediction of cervical intraepithelial neoplasia (CIN) in women with abnormal PAP smear. Gynecol Oncol 2005; 99: 160-8. [CrossRef] 